\title{
Drugs under development for the treatment of functional dyspepsia and related
}

disorders

Tack J., Masuy I, Van den Houte K., Wauters L., Schol J., Vanuytsel T., Vandenberghe A., Carbone F

Translational Research Centre for Gastrointestinal Disorders, University of Leuven, Leuven, Belgium

Keywords: functional dyspepsia, gastroparesis, acid suppressive therapy, prokinetic agents, neuromodulators, phytotherapy, mast cells, eosinophils

Conflict of interests: Jan Tack has given Scientific advice to AlfaWassermann, Allergan, Christian Hansen, Danone, Grünenthal, Ironwood, Janssen, Kiowa Kirin, Menarini, Mylan, Neutec, Novartis, Noventure, Nutricia, Shionogi, Shire, Takeda, Theravance, Tramedico, Truvion, Tsumura, Zealand and Zeria pharmaceuticals and has served on the Speaker bureau for Abbott, Allergan, AstraZeneca, Janssen, Kyowa Kirin, Menarini, Mylan, Novartis, Shire, Takeda, Truvion and Zeria. Tim Vanuytsel has given scientific advice to Dr. Falk, Shire, Takeda, Therachon, Tramedico and Zealand and has served on the speaker bureau for Abbott, Kyowa Kirin, Menarini, Truvion and Will Pharma, No disclosures for the other authors.

Corresponding author: Jan Tack, MD, PhD

Herestraat 49, box 701

3000 Leuven

Belgium

Tel: +3216345514

Fax: +3216330723

jan.tack@med.kuleuven.be 


\begin{abstract}
Introduction: Functional dyspepsia (FD), defined as the presence of chronic functional symptoms originating from the gastroduodenum, is one of the most common functional gastrointestinal disorders. FD is subdivided into postprandial distress syndrome (PDS), with meal-related symptoms such as postprandial fullness and early satiation, and epigastric pain syndrome (EPS), with meal-unrelated symptoms such as epigastric pain or burning. In spite of its prevalence, therapeutic options for FD are very limited, probably reflecting the complex pathophysiology which comprises disorders of gastric sensorimotor function as well as low grade duodenal inflammation. Areas covered: This review summarizes recent and ongoing drug development for FD as identified from a literature search was conducted on Pubmed and other sources. Expert opinion: Proton pump inhibitors (PPIs) are the traditional first-line therapy; potassiumcompetitive acid blockers are being studied. Ongoing drug development focuses on gastric motility with prokinetics (dopamine-2 antagonists and 5-HT4 agonists) and fundus relaxant therapies (acotiamide, azapirones), and on sensitivity with peripherally (guanylate cyclase and cannabinoid agonists) and centrally acting neuromodulators. Drugs under development for gastroparesis may also be efficacious in PDS. There are emerging data with pro- and antibiotics and several studies with phytotherapeutic agents. Duodenal low-grade inflammation is a newly emerging target which may respond also to PPIs, histamine and leukotriene receptor blockers.
\end{abstract}

Keywords: functional dyspepsia, postprandial distress syndrome, epigastric pain syndrome, proton pump inhibitors, prokinetics, histamine receptor blockers, neuromodulators, potassium-competitive acid blockers, herbal medicines 


\section{Article highlights}

- Functional dyspepsia (FD) is one of the most common gastrointestinal disorders, but there are few therapies of established efficacy

- Stronger acid suppressive therapy with potassium-competitive acid blockers have a potential to provide better symptom control through stronger acid suppression

- New prokinetics potentially applicable to FD include dopamine-2 receptor antagonists and 5-HT4 agonists

- Fundic relaxant agents are a new therapeutic approach, including acotiamide and azapirones

- Centrally but also peripherally acting neuromodulators can provide benefit by acting on visceral hypersensitivity

- Low grade duodenal inflammation may be a novel target for therapy, using histamine or leukotriene receptor antagonists, acid suppressive agents and perhaps pro- and antibiotics

- New validated patient reported outcome questionnaires for FD studies are becoming available 


\section{Introduction}

Functional dyspepsia (FD), defined by the Rome IV criteria as recurrent or chronic epigastric symptoms in the absence of organic disease likely to explain them (1), is one of the most common conditions seen in clinical practice. The cardinal symptoms of FD are early satiation, postprandial fullness, epigastric pain and epigastric burning (Table 1). To fulfil the Rome criteria, symptoms have to be severe enough to interfere with usual activities and occur at least 3 days per week over the last 3 months for early satiation and postprandial fullness and 1 day per week for epigastric pain or burning, with symptom onset at least 6 months prior to diagnosis (1).

Two subgroups are identified within FD: the postprandial distress syndrome (PDS) and the epigastric pain syndrome (EPS) (Table 1). The PDS subgroup is characterized by symptom triggering or aggravation by a meal and includes postprandial fullness, early satiation and other postprandially occurring symptoms. The EPS subtype is defined by meal-unrelated symptoms, such as epigastric pain and epigastric burning (1). It is presumed that both subtypes depend on different underlying pathophysiological mechanisms and require specific management approaches (1,2). For the PDS group, pathophysiological research has focused on disordered upper gastrointestinal motility, including impaired gastric accommodation to a meal and delayed gastric emptying (3). More recently, low-grade inflammatory changes in the duodenum, including increased numbers of eosinophils, mast cells and increased mucosal permeability have been a topic of intense research in PDS (4) (Figure 1). In the EPS patients, pathophysiological concepts are less well developed and they include acid-related symptoms, helicobacter pylori gastritis and duodenal lipid sensitivity amongst others. Furthermore, visceral hypersensitivity due to dysfunction of the brain-gut-axis is considered a major determinant of symptom intensity perception in both subgroups (5).

FD, while not life-threatening, has a major impact on quality of life and work productivity and is associated with considerable health care, societal and self-costs $(6,7)$. To date, no therapy of established efficacy is available in most parts of the world. However, due to the high prevalence of the condition, clinicians manage these patients, often by using therapies off-label. The main categories of agents used for FD treatment are proton pump inhibitors (PPIs) and other acid-suppressive agents, prokinetic agents, 
neuromodulators targeting visceral hypersensitivity, probiotic agents and herbal therapies (8).

A major point of controversy in the literature is the relationship of FD, and especially PDS, to (idiopathic) gastroparesis. Gastroparesis is defined as the presence of epigastric symptoms in association with severely delayed gastric emptying without underlying organic obstructive cause (9). The symptom pattern of gastroparesis overlaps strongly with that of PDS, and both require a negative endoscopy and can be associated with delayed gastric emptying. However, nausea and vomiting are considered the cardinal symptoms of gastroparesis, which helps to differentiate it from FD $(9,10)$ (Figure 1). Nevertheless, both entities share common therapeutic approaches, and drugs under development for gastroparesis may benefit FD and vice versa. In addition, major overlap also exists with nausea and vomiting disorders as defined by the Rome consensus (10). Anti-nauseants have also been used for the treatment of FD, especially PDS. Figure 1 summarizes the concept of overlapping functionaly gastroduodenal and motility disorders.

This review provides an overview of all emerging pharmacological treatment options for FD, and also gastroparesis. A literature search was performed to identify relevant full text articles on Pubmed, and on published abstracts of relevant international gastroenterology and neurogastroenterology meetings and from online registries of clinical trials. Used keywords included 'acid suppressive therapy', 'prokinetic agent', 'H. Pylori', 'phytotherapy', 'peppermint oil' 'Rikkunshito', 'iberogast', 'STW5', in combination with 'functional dyspepsia' and also 'gastroparesis'. Furthermore, specific drug names were used as search item in Pubmed and the other databases to identify related articles. An additional search of bibliographies of the included articles was performed to identify studies that were not detected in the initial search. While the intended focus of the review were emerging therapies, it is difficult to define these as availability and state of development or approval of several drugs varies across the world. This is summarized in Table 2. Table 3 summarizes the findings in recent FD treatment trials and selected meta-analyses.

\section{Acid suppressive therapy strategies}


Acid suppressive therapy is the classical first-line therapy for FD (Figure 1). Earlier management algorithms advocated the use of PPIs mainly for EPS, based on the assumption that potential symptomatic benefit could be demonstrated in the pain predominant subgroup, now labelled EPS, but not in the dysmotility-like subgroup, now called PDS $(1,8,11,12)$. The underlying assumption was that some of the EPS was an atypical manifestation of non-erosive reflux disease, or that some of the EPS was attributable to duodenal acid hypersensitivity $(1,12)$. However, a recent meta-analysis reported similar response rates and superiority of PPIs over placebo in both FD subgroups, with a number needed to treat of 11 (13). Moreover, PPIs were found to show higher efficacy than prokinetic agents for improving global FD symptoms in comparative studies. Recently, potassium-competitive acid blockers ( $\mathrm{p}$-cabs), such as vonoprazan, were developed for the treatment of peptic ulcer disease and helicobacter pylori eradication (14). These drugs provide superior control of acid secretion to PPIs, but whether this would generate a higher symptomatic benefit in FD remains to be studied (14). For histamine-2 receptor antagonists, weaker blockers of acid secretion, the recent meta-analysis found similar efficacy to PPIs in controlling symptoms of FD (13). This may seem paradoxical, but actions of acid suppressive agents on low-grade duodenal inflammatory changes may be relevant to their efficacy in FD and are topics of intense studies (see below).

\section{Prokinetic and other motility modifying agents}

Based on the assumption that gastric motility disorders, including delayed gastric emptying and impaired gastric accommodation to a meal, underlie symptoms, prokinetics are often considered the preferred therapeutic approach in PDS $(1,8,15)$ (figure 2). Based on a recent meta-analysis, prokinetic agents are significantly more effective than placebo in reducing FD symptoms, with a $14 \%$ margin over placebo $(13,16,17)$. However, these numbers are mainly based on older studies, and recent prokinetic drug development for FD has been limited. Moreover, prokinetic agents are heterogeneous, belonging to several pharmacological classes with different mechanisms of action on upper gastrointestinal tract motility (8). Finally, there is a lack 
of recent studies evaluating efficacy in FD subgroups as defined by Rome III or Rome IV definitions $(13,16,17)$.

\section{Dopamine-2 receptor antagonists}

An important class of prokinetic agents are the dopamine D2-receptor antagonists. Domperidone, the best known agent in this class, was never approved by the FDA. In Europe, domperidone has long been available over the counter, but, based on recent concerns over risk for prolongation of the QT-interval and increased risk of ventricular arrhythmia, domperidone now has only limited availability in Europe too, and only short-term use is recommended (15). A recent Cochrane review and meta-analysis found insufficient evidence for the efficacy of domperidone in FD $(16,17)$. On the other hand, domperidone is the most frequently used comparator when the efficacy of different prokinetics was evaluated $(16,17)$. While the older available studies show symptomatic benefit in patients with suspected gastroparesis, the effect of domperidone in FD is less clear (13).

Itopride, available in Asia and to some extent in Eastern Europe, is a combined dopamine-2 antagonist and cholinesterase inhibitor. Four out of six controlled trials with itopride in FD showed efficacy, but 2 large phase 3 trials in the West were negative, generating a trend towards efficacy in meta-analysis $(13,15-17)$. These trials suffered from issues with patient and endpoint selection (13), but their negative outcome stopped further development of itopride in the West for several years. A recent study evaluating itopride using validated patient-reported outcome measures suggests efficacy of itopride especially in patients with overlapping PDS-EPS (18).

TAK-906 is a new dopamine-2 and dopamine-3 receptor antagonist with poor penetration in the central nervous system and is devoid of QT prolonging and other cardiovascular adverse effects (19). The drug is currently under development for gastroparesis, but based on the similarities and overlap between idiopathic gastroparesis and PDS, studies evaluating its efficacy in FD should be considered.

\section{$\underline{\text { Serotonin-4 receptor agonists }}$}

Another class of prokinetic agents are the serotonin-4 (5-HT4) receptor agonists. The first 5-HT4-receptor agonist used for treating gastric motility disorders was 
metoclopramide, which is also a D2-receptor antagonist but which received a black box warning for its risk of inducing extrapyramidal symptoms (15). Cisapride, a 5-HT4receptor agonist developed in the 1990s, became the leading prokinetic drug for treatment of upper gastrointestinal hypomotility disorders but was withdrawn from the market for its arrhythmogenic potential, due to its affinity for the human ether-a-gogo (HERG) channel (20). Several other, more selective, $5-\mathrm{HT}_{4}$ receptor agonists have been developed, including mosapride, tegaserod, prucalopride and velusetrag $(8,15,20,21)$. Mosapride is used as a prokinetic agent in many Asian countries, but a controlled trial in Europe failed to show efficacy in FD (15). Both for itopride (see above) and mosapride, differences were observed between Western and Asian studies. While these may reflect differences in patient selection and choice of endpoints, a review of the recent literature indicated that PDS is a more prevalent subtype in Asia, and that GERD co-morbidity is significantly higher in the West (22). The latter may in theory contribute to a lesser efficacy signal of prokinetic therapies focusing on the stomach in Western FD studies.

Tegaserod, a partial 5-HT4 agonist that was originally developed for constipationpredominant irritable bowel syndrome (IBS-C) and functional constipation, was evaluated in clinical trials in FD as well $(15,20,23,24)$. A phase $2 b$ program in patients with at least moderately severe meal-related FD symptoms showed benefit of $6 \mathrm{mg}$ b.i.d. in female patients (23). Two large randomised, placebo-controlled, phase 3 studies used less stringent FD symptom criteria and showed a statistically significant but clinically disappointing effect (24). With the observation of a greater treatment effect in patients with at least moderate or severe symptoms at baseline in the phase 3 studies, and the great similarity of PDS to meal-related FD symptoms as studied in phase 2, a re-evaluation of the therapeutic efficacy of tegaserod in PDS patients according to Rome IV criteria should be considered.

Prucalopride, a highly selective 5-HT4 agonist approved for the treatment of chronic constipation, was recently also evaluated in a cross-over study in patients with gastroparesis. Significant benefit was observed in idiopathic gastroparesis with the 2 $\mathrm{mg}$ dose, and this was associated with significantly enhanced gastric emptying rate (25). The therapeutic potential of a similar or lower dose in FD/PDS still needs to be evaluated, but in the idiopathic gastroparesis group the cardinal symptoms of 
postprandial fullness, early satiation and upper abdominal bloating all improved significantly (25).

Velusetrag, another highly selective 5-HT4 agonist, was recently also evaluated in a phase $2 b$ study for gastroparesis. In controlled trials evaluating 5, 15 and $30 \mathrm{mg}$ doses, velusetrag $30 \mathrm{mg}$ significantly enhanced gastric emptying (26), but significant symptom improvement was only observed with the $5 \mathrm{mg}$ dose. Moreover, idiopathic gastroparesis patients seemed to show a better response to the $5 \mathrm{mg}$ dose over placebo than those with diabetic gastroparesis (27). A phase 3 study in idiopathic gastroparesis is plan,ed.

\section{Acotiamide}

Acotiamide is a first-in-class acetylcholinesterase inhibitor and antagonist at presynaptic M1 and M2 muscarinic receptors, which induces an increase in acetylcholine levels in the synaptic cleft. Through these actions, mechanistic studies showed that acotiamide enhances gastric accommodation and gastric emptying rate. In addition, acotiamide acts on the brain-gut-axis, at least in part through vagal pathways, to inhibit the effects of stress on gastrointestinal functions. Based on studies in Europe and in Japan, acotiamide is well-tolerated and most effective for PDS (28). A single placebo-controlled phase 3 study, followed by an open-label safety study, was carried out in Japan $(29,30)$, leading to approval for this drug for the treatment of FD.

A European one-year open-label study investigating the long-term safety of acotiamide treatment showed no significant clinical safety concerns and showed signs of longterm efficacy based on Leuven Postprandial Distress Scale scores (31). However, pivotal phase 3 studies have not been conducted in the West and the drug is currently only approved in Japan and India.

\section{Azapirones}

Buspirone and tandospirone, 5-hydroxytryptamine $1 \mathrm{~A}$ receptor $\left(5-\mathrm{HT}_{1 \mathrm{~A}}\right)$ agonists with anxiolytic properties, have been studied for their efficacy in FD. This was mainly triggered by their ability to enhance gastric accommodation $(32,33)$, while they tend to slow gastric emptying. A small mechanistic study confirmed symptomatic benefit in association with enhanced gastric accommodation in FD; a large multi-center placebo 
controlled study in Japan confirmed efficacy of tandospirone (34). Side effects are drowsiness, which could potentially be overcome by a peripherally restricted agent, but studies with an experimental 5-HT1A agonist failed to show meaningful efficacy (35).

\section{$\underline{\text { Anti-emetics and other therapies for severe gastroparesis }}$}

As indicated above, there is major overlap between PDS and nausea and vomiting disorders $(3,10)$. Several classes of anti-emetic agents exist, including dopamine-2 antagonists (see-above), 5-HT3 antagonists, histamine-1 antagonists (e.g. promethazine, dimenhydrinate, ...) and NK1-antagonists, and based on their efficacy for nausea they are often used in FD patients too. The efficacy of dopamine-2 antagonists has been summarized above. Case series suggest potential benefit of the 5-HT3 antagonists granisetron or ondansetron, mainly on nausea and vomiting but also on FD symptoms such as postprandial fullness, upper abdominal pain, and early satiation $(36,37)$. In a controlled trial of the NK1-antagonist aprepitant in patients with symptoms suggestive of gastroparesis, symptomatic benefit was reported for several other symptoms including epigastric pain, fullness and bloating (38). Dedicated studies in FD are lacking.

Some therapies are currently or were recently under evaluation for the treatment of severe gastroparesis symptoms. Injection of botulinum toxin, also applied in gastroparesis, failed to show significant benefit over placebo and is therefore not expected to exert efficacy in FD $(39,40)$. These include pyloric peroral endoscopic myotomy (G-POEM) for patients with suspected pyloric dysfunction, the injectable ghrelin analogue relamorelin for diabetic gastroparesis with persistent vomiting and motilin analogues such as camicinal for diabetic gastroparesis (20,21,41-43). While there is overlap between FD, especially PDS, and gastroparesis, it is unclear whether these treatments for severe symptomatic manifestations of gastroparesis may also benefit FD or PDS patients.

\section{$\underline{\text { Combination therapies }}$}

Combined preparations of prokinetic agents with anti-secretory agents have been studied for FD treatment, based on the rationale that symptom generation may depend 
on multiple mechanisms in this heterogeneous condition, and that such combination is more likely to address a meaningful mechanisms in the individual patient than a singlemodality therapy (44-47). However, the available literature has focused on GERD and is less supportive of such gain in FD. Addition of pantoprazole to the herbal prokinetic agent motilitone or addition of an $\mathrm{H} 2$ blocker to acotiamide did not augment the efficacy of the motility agents $(46,47)$.

\section{Neuromodulators and other analgesic agents}

The brain-gut-axis is now acknowledged to play a role in the pathogenesis of FD, especially through the pathophysiological mechanism of visceral hypersensitivity. Indeed, visceral hypersensitivity is a major determinant of symptom severity in FD, and neuromodulators are used to therapeutically target this mechanism, both centrally and peripherally $(48,49)$ (Figure 1$)$.

\section{Centrally acting neuromodulators}

The best-studied neuromodulator in FD is the tricyclic antidepressant amitriptyline. Several studies confirmed efficacy of amitriptyline for FD symptoms, especially in EPS patients, in the absence of a significant effect on gastric sensorimotor function, and also without depression or anxiety accounting for the therapeutic effect $(13,15,50,51)$. In the placebo-controlled study evaluating efficacy of amitryptiline and escitalopram in FD, amitryptiline was superior to placebo and to escitalopram in the EPS subgroup (52). Both SSRIs and SNRIs were studied in FD, but controlled trials failed to demonstrate efficacy $(15,50,52)$. The superiority of tricyclic agents over SSRIs and SNRIs is poorly understood and requires further mechanistic studies.

Mirtazapine, a tetracyclic antidepressant, was shown to improve FD symptoms, quality of life, Gl specific anxiety and nutrient volume tolerance compared to placebo after 8 weeks of treatment in FD patients with weight loss and no major depression or anxiety (53). The mechanism of action is uncertain, especially as gastric sensorimotor function was not altered by mirtazapine in healthy subjects (54), but (central) $5-\mathrm{HT}_{2 \mathrm{C}}$ receptor 
antagonism as well as (peripheral) $\mathrm{H}_{1}$ receptor antagonism (see below) have been implicated in the therapeutic effect (53).

\section{Peripherally acting neuromodulators}

Guanylate cyclase agonists, such as linaclotide, are used for the treatment of IBS-C and chronic constipation, because of their effects on intestinal fluid secretion and on visceral hypersensitivity (8). IW-9179, an investigational guanylate cyclase-C (GC-C) agonist designed to target the upper gastrointestinal tract (55) was evaluated in a small pilot study in FD patients not suffering from overlapping conditions, including IBS. Although underpowered, there was a suggestion of decreased symptom intensity with the active agent over placebo. The main side effect was diarrhoea (56). Subsequently, the drug was studied in diabetic gastroparesis but development was halted for lack of robust efficacy (58).

Endocannabinoid receptor binding studies suggested decreased endocannabinoid tone in FD (58), and mechanistic observations revealed that CB1 receptor antagonism is able to induce gastric motility disorders such as impaired accommodation (59). Based on these findings, there is a potential for application of endocannabinoid agonists or endocannabinoid degradation inhibitors in FD. In a small pilot study, the MAG lipase inhibitor ABX-1431 failed to provide significant mechanistic or symptomatic benefit (NCT02875678). Of note, however, this pilot study was performed in only 4 FD patients and used an acute dosing regimen (phase 2a). Olorinab is a peripherallyrestricted, highly selective cannabinoid type 2 agonist. In a study in patients with quiescent Crohn's disease, olorinab significantly improved symptoms of abdominal pain (60). The drug has potential for therapeutic application in gastrointestinal chronic painful conditions, including FD, with EPS as the primary target group as this is a paindominated group.

\section{Pre-, pro- and antibiotics}

Helicobacter pylori eradication has a small but significant beneficial effect on symptoms in H.pylori positive FD patients, but in the Western world, this is a minority 
and the beneficial effect reaches significance only several months after the treatment (61). Whether other microbiota species are relevant has only began to be explored. Preliminary observations suggest a possible role for altered duodenal microbiota in the symptom profile and severity in FD (62).

Probiotic containing products have become popular as self-management or prescribed treatment for bowel symptoms, while FD has been less well studied. In a study in 116 FD patients, Lactobacillus gasseri OLL2716 tended to improve symptoms over placebo and there was a higher elimination rate of symptoms compared to placebo (63). In a controlled trial from Hong Kong, rifaximin 400 mg t.i.d. for 2 weeks, with 8 weeks followup, was superior to placebo in providing adequate relief $(78 \%$ vs. $52 \%, P=0.02)$ in 86 $H$. pylori negative FD patients. Rifaximin was well tolerated, and belching and postprandial fullness/bloating seemed the most responsive symptoms (64). Confirmation in larger multi-center studies is needed.

\section{Herbal medicines}

The lack of availability of effective pharmacological therapies for FD has sparked the interest in phytomedical treatment (herbal medicine). Compared to pharmacological agents, which often target a single receptor, herbal remedies have the potential advantage that they can exert a broader range of pharmacological effects. Furthermore, patients often presume they are better tolerated and devoid of major side effects, although this is not firmly established. For instance, the herbal medicine iberogast (STW5), which is composed of 9 different extracts, has been the subject of several controlled trials in FD (65). Meta-analyses have established the efficacy of Iberogast in improving FD symptoms, although it is less clear which individual symptoms respond best and whether there is a difference between EPS and PDS (65).

Recent studies have focused on the combination of peppermint oil and carraway oil in FD. Three placebo-controlled, randomized trials reported superiority of the combination of peppermint oil and caraway oil over placebo in reducing FD symptoms. May et al. reported a rate of improvement of $66 \%$ after peppermint/caraway oil treatment compared to $20.9 \%$ after placebo (66). Furthermore, Rich et al. reported an 
improvement in FD symptoms in $88 \%$ of the patients after peppermint/caraway oil treatment compared to $55.4 \%$ after placebo (67). In a preliminary report from the U.S.A., Chey et al. reported symptom improvement with the combination in $78 \%$ of PDS patients and $72 \%$ of EPS patients compared to $50 \%$ and $40 \%$ in the placebo groups, respectively (68). Mechanistic studies in healthy volunteers demonstrated that acute administration of peppermint oil decreases intragastric pressure and inhibits gastroduodenal motility $(69,70)$.

Rikkunshito is a multi-herbal combination preparation from Japan, which showed efficacy above placebo in improving FD symptoms in 2 large studies in Japan (71,72). A follow-up analysis of the trial by Suzuki et al. indicated that response to Rikkunshito was associated with low baseline des-acyl ghrelin levels, abstinence of alcohol abuse and positive $\mathrm{H}$. Pylori status $(72,73)$. One of the suggested mechanisms of action is increased release and decreased inactivation of ghrelin.

\section{Targeting mucosal inflammatory changes}

Mucosal protective agents are frequently used for treatment of dyspeptic symptoms in Asia. Rebamipide, an agent whose action involves cyclooxygenase actvation and inhibition of inflammatory processes in the gastric and perhaps also duodenal mucosa, is the most frequently used agent. A meta-analysis of rebamipide controlled studies found significant efficacy in organic dyspepsia (nonsteroidal anti-inflammatory drug induced gastropathy, H. pylori associated lesions or ulcers), but also a tendency for benefit in (a lower number of) functional dyspepsia studies (74). In view of the emergency of mucosal alterations in FD, further studies with mucosal protective agents seem warranted.

Development of novel therapeutic approaches for FD has largely focused on the stomach, with acid suppressive and prokinetic drugs as the main therapeutic options. With recent pathophysiological studies identifying low-grade inflammation in the duodenum, including increased eosinophil and mast cell counts and activation status, as a potentially relevant pathophysiological mechanism, this is a target for novel therapeutic approaches (Figure 2). Duodenal eosinophils may be a hitherto 
unrecognised target for acid suppressive therapy in FD, as 2 early reports showed that PPIs decreased duodenal eosinophil counts and improved symptoms in FD $(75,76)$.

Histamine, the main mediator released from mast cells, is another potential duodenal target in FD. Recent meta-analyses already found that histamine-2 receptor antagonists, had similar efficacy to PPIs in controlling symptoms of FD, although their acid-suppressive potential is clearly lower (12). Furthermore, histamine-1 receptor antagonists have anti-emetic properties, and mirtazapine's pharmacological actions include histamine-1 receptor antagonism. These considerations, together with a putative crucial role for histamine as mast cell mediator, provide the rationale for revisiting histamine receptor antagonism in FD. In a retrospective case series from Australia, combined histamine-1 and -2 receptor blockade provided symptomatic benefit which tended to be higher in those with more elevated duodenal eosinophil counts at baseline (77). In addition, a pediatric case series reported beneficial response to the leucotriene-1 receptor antagonist montelukast, or its combination with combined histamine-1 and -2 receptor antagonists $(78,79)$.

\section{Expert opinion}

Large epidemiology studies surveying 5921 subjects in 3 countries, using the Rome IV definitions of functional gastrointestinal disorders, established FD as one of the most prevalent conditions. With a Rome IV FD prevalence ranging between 8 and $12 \%$ of the population, the condition is approximately twice as common as IBS $(3,6,80-82)$. Taking into account its prevalence and associated health economic costs, it is surprising that there are virtually no drugs of established efficacy, and drug development for FD is of a very modest magnitude $(1,3,7)$.

One reason is probably the pharmaceutical industry focus on gastroesophageal reflux disease (GERD) by the end of the 1990s, leading to a steady decline in FD diagnoses in the U.S.A, paralleled by a rise in GERD diagnoses (83). Related to this issue is the dominant trend in the U.S.A. to focus on gastroparesis, while almost ignoring FD. Here, underlying factors are the historical focus on delayed gastric emptying as a mechanism of symptom generation, the belief that cisapride, a blockbuster prokinetic agent 
available by the end of the 1990s, was mainly used for the treatment of gastroparesis, and the assumption that gastroparesis presents a more tangible target for drug development than FD $(9,17)$. However, to date, no drug has been approved for gastroparesis, so also for this indication a regulatory approval track has not been established.

In the past, the focus of drug development and dose selection for gastroparesis was primarily on the gastric emptying rate, with secondary assessment of symptoms $(84,85)$. Now over a decade ago, regulatory agencies like FDA and EMA shifted the focus of pharmacological innovation to a need to provide evidence of relevant improvement in symptoms as experienced by the patients, reflected in the published guidance for PRO development (86). Over time, it became clear that there is a very poor relationship between enhancement of gastric emptying and symptom improvement with drug therapy in gastroparesis (87) and in its latest guidance for gastroparesis, FDA has abandoned the need to demonstrate enhancement of gastric emptying for newly developed gastroparesis drugs (88).

With a focus on symptoms and especially without overruling need to demonstrate efficacy on gastric emptying rate enhancement, the evaluation of efficacy in gastroparesis trials comes close to that of symptom evaluation in FD, and especially PDS. Indeed, efficacy evaluation in gastroparesis focuses on a set of symptoms which show major overlap with the symptoms in FD and especially PDS (89). The main difference is that a gastroparesis trial enrolls patients with established delayed emptying, but studies have already established that the degree of emptying delay and its evolution do not determine treatment outcome (87).

Based on this consideration, most agents currently under phase 2 or phase 3 evaluation for gastroparesis have the potential to improve symptoms in FD too. In fact, recent phase 2 studies showed that symptomatic benefit was mainly observed with the lower dose ranges, did not increase with higher dosing and did not parallel the effects on gastric emptying rate $(18,22,27,43)$. Symptom diaries for gastroparesis evaluate symptom intensities for postprandial fullness, early satiation, epigastric pain, nausea and vomiting $(19,25,42,43,90)$; only the latter 3 are no cardinal FD symptoms. Hence, efficacy for gastroparesis symptoms may also extend to FD symptoms, but of course requires dedicated studies in this population. 
In addition, drug development for FD has also suffered from a lack of validated endpoints. Recently, the Leuven Postprandial Distress Scale was validated and received support from the European Medicines Agency as patient-reported outcome for PDS studies (91). In the U.S.A., the Functional Dyspepsia Symptom Diary is being developed according to FDA guidance (92).

On the other hand, drug development for FD has been hampered by the presumed pathophysiological heterogeneity of the condition and overlap with GERD and IBS (1,3$4,9,10)$. The Rome III consensus proposed the subdivision into PDS, with meal-related symptoms, triggered by food ingestion such as postprandial fullness, early satiation and EPS, characterized by meal-unrelated symptoms such as epigastric pain and burning (93). While epidemiological studies supported the existence and separation of thesis entities in the general population in different settings, a large overlap between PDS and EPS was found in clinical practice $(2,94)$. The Rome IV consensus aimed at diminishing this overlap by considering all postprandially occurring symptoms as part of PDS (1), but to date there is a lack of clinical trials and outcome studies in specific Rome IV-defined FD subgroups. Only one preliminary study suggests that postprandial pain may indeed respond to prokinetic therapy (18). If confirmed, this opens the potential for many of the novel prokinetics, currently mainly under evaluation for gastroparesis, to provide symptom relief to a large subset of FD patients, but confirmation in dedicated studies is needed.

Besides the focus on prokinetics, duodenal low-grade immune activation, and perhaps the duodenal microbiota, are likely targets for further drug development in FD (61-64, 75)79), but here too confirmation in high-quality multi-center studies will be key. Also the visceral analgesic approach, especially with peripherally acting neuromodulators $(55,60)$ offers potentially attractive targets for controlling EPS and EPS/PDS overlap. However, no PROs for EPS have been formally validated to date. Finally, herbal medicine approaches are increasingly popular, and they hold the potential of combining targeting of multiple receptors with an attractive tolerance profile. However, convincingly confirming their efficacy requires studies that are performed with the same rigor as classical drug development trials. 


\section{Conclusion}

The Rome IV consensus consolidated the subdivision of PDS and EPS, and grouped together all postprandially occurring symptoms in FD as PDS, but to date there are few therapeutic trials according to this consensus. P-cabs have the potential to be more efficacious than PPIs in FD, but confirmatory studies are needed. Ongoing drug development focuses on prokinetics, mainly based on dopamine-2 antagonism and 5HT4 agonism properties. Fundus relaxing agents under development include acotiamide and azapirones. Visceral hypersensitivity can be targeted by centrally acting neuromodulators like antidepressants, but observations with guanylate cyclase agonists and cannabinoid agonists suggest that a peripheral approach may also be possible. Besides the focus on prokinetics, duodenal low-grade immune activation, and perhaps the duodenal microbiota, are novel therapeutic targets in FD. Emerging research is also focusing on probiotics, antibiotics and phytotherapeutic agents. 


\section{References}

1. Stanghellini V, Talley N, Chan F, Hasler B, Malagelada J, Suzuki H and Tack J. Functional Gastroduodenal Disorders. Gastroenterology 2016, May;150(6):138092.

2. Tack J, Talley NJ. Functional dyspepsia-symptoms, definitions and validity of the Rome III criteria. Nat Rev Gastroenterol Hepatol. 2013, 10: 134-41.

3. Van den Houte K, Carbone F, Tack J. Postprandial distress syndrome: stratification and management. Expert Rev Gastroenterol Hepatol. 2019 Aug;3(4):337-43.

4. Carbone F, Tack J. Gastroduodenal mechanisms underlying functional gastric disorders. Dig Dis. 2014;32(3):222-9.

5. Simrén M, Törnblom H, Palsson OS, van Tilburg MA, Van Oudenhove L, Tack J, Whitehead WE. Visceral hypersensitivity is associated with GI symptom severity in functional GI disorders: consistent findings from five different patient cohorts. Gut. 2018 Feb;67(2):255-262.

6. Piessevaux H, de Winter B, Louis E, Muls V, de Looze D, Pelckmans P, Deltenre $M$, Urbain D, Tack J. Dyspeptic symptoms in the general population: a factor and cluster analysis of symptom groupings. Neurogastroenterol Motil. 2009 Apr;21(4):378-88.

7. Lacy BE, Weiser KT, Kennedy AT, Crowell MD, Talley NJ. Functional dyspepsia: the economic impact to patients. Aliment Pharmacol Ther. 2013 Jul;38(2):170-7.

8. Tack J, Camilleri M. New developments in the treatment of gastroparesis and functional dyspepsia. Curr Opin Pharmacol. 2018 Dec;43:111-117.

9. Stanghellini V, Tack J. Gastroparesis: separate entity or just a part of dyspepsia? Gut. 2014 Dec; 63(12):1972-8.

10. Jehangir A, Parkman HP. Rome IV Diagnostic Questionnaire Complements Patient Assessment of Gastrointestinal Symptoms for Patients with Gastroparesis Symptoms. Dig Dis Sci. 2018 Sep;63(9):2231-2243.

11. Quigley EM, Lacy BE. Overlap of functional dyspepsia and GERD--diagnostic and treatment implications. Nat Rev Gastroenterol Hepatol. 2013 Mar;10(3):175-86. 
12. Moayyedi P, Delaney BC, Vakil N, Forman D, Talley NJ. The efficacy of proton pump inhibitors in nonulcer dyspepsia: a systematic review and economic analysis. Gastroenterology. 2004;127(5):1329-1337

13. Moayyedi P, Lacy BE, Andrews CN, Enns RA, Howden CW, Vakil N. ACG and CAG Clinical Guideline: Management of Dyspepsia. Am J Gastroenterol. 2018 Jul;112(7):988-1013.

14. Asaoka D, Nagahara A, Hojo M, Matsumoto K, Ueyama H, Matsumoto K, Izumi K, Takeda T, Komori H, Akazawa Y, Shimada Y, Osada T, Watanabe S. Efficacy of a potassium-competitive acid blocker for improving symptoms in patients with reflux esophagitis, non-erosive reflux disease, and functional dyspepsia. Biomed Rep. 2017 Feb;6(2):175-180.

15. Masuy I, Van Oudenhove L, Tack J. Review article: treatment options for functional dyspepsia. Aliment Pharmacol Ther. 2019 May;49(9):1134-1172.

16. Pittayanon R, Yuan Y, Bollegala NP, Khanna R, Leontiadis GI, Moayyedi P. Prokinetics for functional dyspepsia. Cochrane Database Syst Rev. 2018 Oct 18;10:CD009431.

17. Pittayanon R, Yuan Y, Bollegala NP, Khanna R, Lacy BE, Andrews CN, Leontiadis GI, Moayyedi P. Prokinetics for Functional Dyspepsia: A Systematic Review and Meta-Analysis of Randomized Control Trials. Am J Gastroenterol. 2019 Feb;114(2):233-243. doi: 10.1038/s41395-018-0258-6.

18. Carbone F, Vandenberghe A, Holvoet L, Vanuytsel T, Jones MP, Tack JF. 383 The Therapeutic Outcome of Itopride in Functional Dyspepsia Postprandial Distress Syndrome: A Double-Blind Randomized, Multicenter, Placebo-Controlled Study. Gastroenterology. 2018;154(6):S-91.

19. Dukes GE, Scimia C, Kuo B, Zhang W, Gupta S, Chen C, et al. Safety, Tolerability, and Pharmacodynamics of TAK-906, A Dopamine 2,3 Antagonist, in Patients with Diabetic or Idiopathic Gastroparesis. Neurogastroenterol Motil. Aug 2019, in press (abstract).

20. Tack J, Camilleri M, Chang L, Chey WD, Galligan JJ, Lacy BE, Müller-Lissner S, Quigley EM, Schuurkes J, De Maeyer JH, Stanghellini V. Systematic review: cardiovascular safety profile of 5-HT(4) agonists developed for gastrointestinal disorders. Aliment Pharmacol Ther. 2012 Apr;35(7):745-67. 
21. Tack J, Van den Houte K, Carbone F. The Unfulfilled Promise of Prokinetics for Functional Dyspepsia/Postprandial Distress Syndrome. Am J Gastroenterol. 2019 Feb;114(2):204-206 .

22. Mahadeva S, Ford AC. Clinical and epidemiological differences in functional dyspepsia between the East and the West. Neurogastroenterol Motil. 2016 Feb;28(2):167-74.

23. Tack J. A phase II placebo controlled randomized trial with tegaserod in functional dyspepsia patients with normal gastric emptying. Gastroenterology. 2002;122:154.

24. Vakil N, Laine L, Talley NJ, Zakko SF, Tack J, Chey WD, Kralstein J, Earnest DL, Ligozio G, Cohard-Radice M. Tegaserod treatment for dysmotility-like functional dyspepsia: results of two randomized, controlled trials. Am J Gastroenterol. 2008 Aug;103(8):1906-19.

25. Carbone F, Van den Houte K, Clevers E, Andrews CN, Papathanasopoulos A, Holvoet L, Van Oudenhove L, Caenepeel P, Arts J, Vanuytsel T and Tack J. Prucalopride in Gastroparesis: A Randomized Placebo-Controlled Crossover Study. Am J Gastroenterol 2019; 114(8):1265-1274.

* Pilot study showing efficacy of prucalopride in idiopathic gastroparesis (FD with delayed emptying).

26. Ahn A, Barnes C, Shaywitz D, Gimaldi M and Canafax DM. Velusetrag Improves Gastric Emptying Time in Subjects With Diabetic or Idiopathic Gastroparesis. Gastroenterology 2015; 148, Issue 4, S-507 (abstract).

27. Abell T, Kuo B, Esfandyari T, Canafax D, Camerini R, Grimaldi M, Viscomi GC, Renzulli C, Zhou K, Nguyen D, Barnes C and McCallum RW. Velusetrag improves gastroparesis both in symptoms and gastric emptying in patients with diabetic or idiopathic gastroparesis in a 12-week global phase 2B study. Gastroenterology 2019 Vol. 156, Issue 6, S164 (abstract).

28. Matsueda K, Hongo M, Tack J, Saito Y, Kato H. A placebo-controlled trial of acotiamide for meal-related symptoms of functional dyspepsia. Gut. 2012 Jun;61(6):821-8.

29. Altan E, Masaoka T, Farré R, Tack J. Acotiamide, a novel gastroprokinetic for the treatment of patients with functional dyspepsia: postprandial distress syndrome. Expert Rev Gastroenterol Hepatol. 2012 Sep;6(5):533-44. 
30. Matsueda K, Hongo M, Ushijima S, Akiho H. A long-term study of acotiamide in patients with functional dyspepsia: results from an open-label phase III trial in Japan on efficacy, safety and pattern of administration. Digestion. 2011;84(4):261-8.

31. Tack J, Pokrotnieks J, Urbonas G, Banciu C, Yakusevich V, Bunganic I, Törnblom H, Kleban Y, Eavis P, Tsuchikawa M, Miyagawa T. Long-term safety and efficacy of acotiamide in functional dyspepsia (postprandial distress syndrome)-results from the European phase 3 open-label safety trial. Neurogastroenterol Motil. 2018 Jun;30(6):e13284.

* Long-term safety and efficacy European multi-center study of acotiamide in FD

32. Van Oudenhove L, Kindt S, Vos R, Coulie B, Tack J. Influence of buspirone on gastric sensorimotor function in man. Aliment Pharmacol Ther. 2008 Dec 1;28(1112):1326-33.

33. Tack J, Janssen P, Masaoka T, Farré R, Van Oudenhove L. Efficacy of buspirone, a fundus-relaxing drug, in patients with functional dyspepsia. Clin Gastroenterol Hepatol. 2012 Nov;10(11):1239-45.

34. Miwa H, Nagahara A, Tominaga K, Yokoyama T, Sawada Y, Inoue K, Ashida K, Fukuchi T, Hojo M, Yamashita H, Tomita T, Hori K, Oshima T. Efficacy of the 5HT1 A agonist tandospirone citrate in improving symptoms of patients with functional dyspepsia: a randomized controlled trial. Am J Gastroenterol. 2009 Nov;104(11):2779-87.

35. Tack J, van den Elzen B, Tytgat G, Wajs E, van Nueten L, de Ridder F, Boeckxstaens G. A placebo-controlled trial of the 5-HT agonist R-137696 on symptoms, visceral hypersensitivity and on impaired accommodation in functional dyspepsia. Neurogastroenterol Motil. 2009 Jun;21(6):619-26, e23-4

36. Midani D, Parkman HP. Granisetron Transdermal System for Treatment of Symptoms of Gastroparesis: A Prescription Registry Study. J Neurogastroenterol Motil 2016; 22(4): 650-5.

37. Simmons K, Parkman HP. Granisetron transdermal system improves refractory nausea and vomiting in gastroparesis. Dig Dis Sci 2014; 59(6): 1231-4.

38. Pasricha PJ, Yates KP, Sarosiek I, et al. Aprepitant Has Mixed Effects on Nausea and Reduces Other Symptoms in Patients With Gastroparesis and Related Disorders. Gastroenterology 2018; 154(1): 65-76 e11. 
39. Arts J, Holvoet L, Caenepeel P, et al. Clinical trial: a randomized-controlled crossover study of intrapyloric injection of botulinum toxin in gastroparesis. Aliment Pharmacol Ther 2007; 26(9): 1251-8.

40. Friedenberg FK, Palit A, Parkman HP, Hanlon A, Nelson DB. Botulinum toxin A for the treatment of delayed gastric emptying. Am J Gastroenterol 2008; 103(2): 416-23.

41. Khoury T, Mizrahi M, Mahamid M, et al. State of the art review with literature summary on gastric peroral endoscopic pyloromyotomy for gastroparesis. J Gastroenterol Hepatol 2018; 33(11): 1829-33.

42. Camilleri M, McCallum RW, Tack J, Spence SC, Gottesdiener K, Fiedorek FT. Efficacy and Safety of Relamorelin in Diabetics With Symptoms of Gastroparesis: A Randomized, Placebo-Controlled Study. Gastroenterology 2017; 153(5): 124050 e2.

43. Barton ME, Otiker T, Johnson LV, et al. A Randomized, Double-Blind, PlaceboControlled Phase II Study (MOT114479) to Evaluate the Safety and Efficacy and Dose Response of 28 Days of Orally Administered Camicinal, a Motilin Receptor Agonist, in Diabetics With Gastroparesis. Gastroenterology 2014; 146(5): S20.

44. Agarwal S, Gowda KV, Mandal U, Ghosh D, Bose A, Sarkar AK, Chattaraj TK, Pal TK. Bioequivalence study of a sustained release fixed dose combination capsule containing esomeprazole and domperidone in healthy subjects.

Arzneimittelforschung. 2007;57(5):274-7.

45. Choi HY, Noh YH, Jin SJ, Kim YH, Kim MJ, Sung H, Jang SB, Lee SJ, Bae KS, Lim HS. Bioavailability and tolerability of combination treatment with revaprazan $200 \mathrm{mg}+$ itopride $150 \mathrm{mg}$ : a randomized crossover study in healthy male Korean volunteers. Clin Ther. 2012 Sep;34(9):1999-2010.

46. Jung HK, Lee KJ, Choi MG, Park H, Lee JS, Rhee PL, Kim N, Park K, Choi SC, Lee OY, Huh KC, Song GA, Hong SJ, Sohn Cl, Jung HY, Lee YC, Rew JS, Jee SR, Kwon JG. Efficacy of DA-9701 (Motilitone) in Functional Dyspepsia Compared to Pantoprazole: A Multicenter, Randomized, Double-blind, Noninferiority Study. J Neurogastroenterol Motil. 2016 Apr 30;22(2):254-63.

47. Hojo M, Nagahara A, Asaoka D, Takeda T, Izumi K, Matsumoto K, Ueyama H, Shimada Y, Matsumoto K, Nojiri S, Watanabe S. A Randomized, Double-Blind, Pilot Study of the Effect of Famotidine on Acotiamide Treatment for Functional Dyspepsia. Digestion. 2017;96(1):5-12. 
48. Simrén M, Törnblom H, Palsson OS, van Tilburg MAL, Van Oudenhove L, Tack J, Whitehead WE. Visceral hypersensitivity is associated with GI symptom severity in functional Gl disorders: consistent findings from five different patient cohorts. Gut. 2018 Feb;67(2):255-262.

49. Drossman DA, Tack J, Ford AC, Szigethy E, Tornblom H, Van Oudenhove L. Neuromodulators for Functional Gastrointestinal Disorders (Disorders of GutBrain Interaction): A Rome Foundation Working Team Report. Gastroenterology. 2018;154(4):1140-1171.e1141

50. Talley NJ, Locke GR, Saito YA, et al. Effect of Amitriptyline and Escitalopram on Functional Dyspepsia: A Multicenter, Randomized Controlled Study. Gastroenterology. 2015;149(2):340-349.e342.

${ }^{* *}$ Landmark study showing efficacy of amitriptyiline but not escitalopram in FD.

51. Lacy B, Saito Y, Camilleri M, Bouras E, Dibaise JK, Herrick LM, Szarka LA, Tilkes R, Zinsmeister AR, and Talley NJ. Effects of Antidepressants on Gastric Function in Patients with Functional Dyspepsia. Am. J. Gastroenterol. 2018; 113: 216-24.

52. van Kerkhoven LA, Laheij RJ, Aparicio N, et al. Effect of the antidepressant venlafaxine in functional dyspepsia: a randomized, double-blind, placebocontrolled trial. Clin Gastroenterol Hepatol. 2008;6(7):746-75.

53. Tack J, Ly HG, Carbone F, et al. Efficacy of Mirtazapine in Patients With Functional Dyspepsia and Weight Loss. Clin Gastroenterol Hepatol. 2016;14(3):385-392.e384.

54. Carbone F, Vanuytsel T, Tack J. The effect of mirtazapine on gastric accommodation, gastric sensitivity to distention, and nutrient tolerance in healthy subjects. Neurogastroenterol Motil. 2017;29(12).

55. Kessler M, Solinga R, Zimmer D, Forsyth S, Wachtel D, Cali BM and Currie M. IW-9179, a Phosphopeptide Designed to Target the Upper Gastrointestinal Tract, Is More Potent at Acidic pH and Is Rapidly Metabolized In Vitro in Rodent Intestinal Fluid. Gastroenterology 2015; 148: 4, Supplement 1, S-823 (abstract).

56. Tack J, Fitch D, Shao J, O'Dea C, Curre M and Johnston J. Evaluation of Daily GI Symptoms in a Phase 2a Study of IW-9179 in Functional Dyspepsia (abstract \#P1637). Am J Gastroenterol 2014; 109:S637-S638.

57. Ironwood press release:

https://investor.ironwoodpharma.com/default.aspx?Sectionld=5cc5ecae-6c48- 
4521-a1 ad-480e593e4835\&Languageld $=1 \&$ PressReleaseld $=7 \mathrm{~b} 388 \mathrm{bfc}-3 \mathrm{~d} 82$ 4f4a-8620-a802008a95ce

58. Ly HG, Ceccarini J, Weltens N, Bormans G, Van Laere K, Tack J, Van Oudenhove L. Increased cerebral cannabinoid-1 receptor availability is a stable feature of functional dyspepsia: a [F]MK-9470 PET study. Psychother Psychosom. 2015;84(3):149-58.

59. Ameloot K, Janssen P, Scarpellini E, Vos R, Boesmans W, Depoortere I, Vanden Berghe $\mathrm{P}$, Tack J. Endocannabinoid control of gastric sensorimotor function in man. Aliment Pharmacol Ther. 2010 May;31(10):1123-31

60. Higgins P, Ginsburg D, Gilder K, Walsh B, English B, Turner S, Klassen P, Hanauer S, Barish C, Yacyshyn B. P418 Safety and efficacy of olorinab, a peripherally restricted, highly-selective, cannabinoid receptor 2 agonist in a phase 2A study in chronic abdominal pain associated with Crohn's disease. Ecco 2019, P418.

61. Sugano K, Tack J, Kuipers EJ, Graham DY, El-Omar EM, Miura S, Haruma K, Asaka M, Uemura N, Malfertheiner P; faculty members of Kyoto Global Consensus Conference. Kyoto global consensus report on Helicobacter pylori gastritis. Gut 64, 1353-1367.

62. Zhong L, Shanahan ER, Raj A, Koloski NA, Fletcher L, Morrison M, Walker MM, Talley NJ, Holtmann G. Dyspepsia and the microbiome: time to focus on the small intestine. Gut. 2017 Jun;66(6):1168-1169.

63. Igarashi M, Nakae H, Matsuoka T, et al. Alteration in the gastric microbiota and its restoration by probiotics in patients with functional dyspepsia. BMJ Open Gastro 2017;3:e000144.

64. Tan VP, Liu KS, Lam FY, Hung IF, Yuen MF, Leung WK. Randomised clinical trial: rifaximin versus placebo for the treatment of functional dyspepsia. Aliment Pharmacol Ther. 2017 Mar;45(6):767-776.

* Study showing efficacy of the broad-spectrum poorly absorbable antibiotic rifaximin in Helicobacter pylori negative FD patients.

65. Melzer J, Rösch W, Reichling J, Brignoli R, Saller R. Meta-analysis: phytotherapy of functional dyspepsia with the herbal drug preparation STW 5 (Iberogast). Aliment Pharmacol Ther. 2004 Dec;20(11-12):1279-87. 
66. May B, Kohler S, Schneider B. Efficacy and tolerability of a fixed combination of peppermint oil and caraway oil in patients suffering from functional dyspepsia. Aliment Pharmacol Ther. 2000;14(12):1671-1677.

67. Rich G, Shah A, Koloski N, Funk P, Stracke B, Köhler S, Holtmann G. A randomized placebo-controlled trial on the effects of Menthacarin, a proprietary peppermint- and caraway-oil-preparation, on symptoms and quality of life in patients with functional dyspepsia. Neurogastroenterol Motil. 2017 Nov;29(11).

68. Chey WD, Lacy BE, Cash BD, Epstein M, Shah SM. Sa1619 - Efficacy of Caraway Oi//L-Menthol Plus Usual Care vs Placebo Plus Usual Care, in Functional Dyspepsia Patients with Post-Prandial Distress (PDS) or Epigastric Pain (EPS) Syndromes: Results from a us RCT. Gastroenterology. 2017;152(5):S307 (abstract).

69. Papathanasopoulos A, Rotondo A, Janssen P, et al. Effect of acute peppermint oil administration on gastric sensorimotor function and nutrient tolerance in health. Neurogastroenterol Motil. 2013;25(4):e263-271.

70. Micklefield G, Jung O, Greving I, May B. Effects of intraduodenal application of peppermint oil (WS(R) 1340) and caraway oil (WS(R) 1520) on gastroduodenal motility in healthy volunteers. Phytother Res. 2003;17(2):135-140.

71. Suzuki H, Matsuzaki J, Fukushima Y, Suzaki F, Kasugai K, Nishizawa T, Naito Y, Hayakawa T, Kamiya T, Andoh T, Yoshida H, Tokura Y, Nagata H, Kobayakawa M, Mori M, Kato K, Hosoda H, Takebayashi T, Miura S, Uemura N, Joh T, Hibi T, Tack J; Rikkunshito study group. Randomized clinical trial: rikkunshito in the treatment of functional dyspepsia--a multicenter, double-blind, randomized, placebo-controlled study. Neurogastroenterol Motil. 2014 Jul;26(7):950-61.

72. Tominaga K, Sakata $Y$, Kusunoki H, Odaka T, Sakurai K, Kawamura O, Nagahara A, Takeuchi T, Fujikawa Y, Oshima T, Kato M, Furuta T, Murakami K, Chiba T, Miwa H, Kinoshita Y, Higuchi K, Kusano M, Iwakiri R, Fujimoto K, Tack JF, Arakawa T. Rikkunshito simultaneously improves dyspepsia correlated with anxiety in patients with functional dyspepsia: A randomized clinical trial (the DREAM study). Neurogastroenterol Motil. 20182018 Jul;30(7):e13319.

\footnotetext{
* Study showing efficacy of the Japanese Kampo Medicine preparation Rikkunshito in FD.
} 
73. Togawa K, Matsuzaki J, Kobayakawa M, et al. Association of baseline plasma des-acyl ghrelin level with the response to rikkunshito in patients with functional dyspepsia. J Gastroenterol Hepatol. 2016;31(2):334-341.

74. Jaafar MH, Safi SZ, Tan MP, Rampal S, Mahadeva S. Efficacy of Rebamipide in Organic and Functional Dyspepsia: A Systematic Review and Meta-Analysis. Dig Dis Sci. 2018 May;63(5):1250-1260.

75. Potter MDE, Wood NK, Walker MM, et al. Proton pump inhibitors and suppression of duodenal eosinophilia in functional dyspepsia. Gut 2018;::gutjnl-2018-316878. doi:10.1136/gutjnl-2018-316878.

76. Wauters L, Frings D, Lambaerts M, Accarie A, Toth J, De Hertogh G, Farre R, Tack $J$ and Vanuytsel T. Proton pump inhibitors reduce duodenal hyperpermeability, duodenal eosinophilia and symptoms in functional dyspepsia patients by acid-independent mechanisms. Neurogastroenterology and Motility 2019; august; in press (abstract).

77. Potter MDE, Goodsall TM, Walker MM, et al. Dual histamine blockade for the treatment of adult functional dyspepsia: a single centre experience. Gut 2019 (Epub ahead of print)

78. Friesen CA, Kearns GL, Andre L, et al. Clinical efficacy and pharmacokinetics of montelukast in dyspeptic children with duodenal eosinophilia. J Pediatr Gastroenterol Nutr 2004;38:343-51.

79. Friesen CA, Sandridge L, Andre L, et al. Mucosal eosinophilia and response to $\mathrm{H} 1 / \mathrm{H} 2$ antagonist and cromolyn therapy in pediatric dyspepsia. Clin Pediatr (Phila) 2006;45:143-7.

80. Palsson OS, Van Tilburg MAI, Sperber A, Spiegel B, Tack J, Walker L, Yang Y and Whitehead W. Rome IV Diagnostic Questionnaires and Tables for Investigators and Clinicians. Gastroenterology 2016, May;150(6):1481-91.

81. Aziz I, Palsson OS, Törnblom H, Sperber AD, Whitehead WE, Simrén M. Epidemiology, clinical characteristics, and associations for symptom-based Rome IV functional dyspepsia in adults in the USA, Canada, and the UK: a crosssectional population-based study. Lancet Gastroenterol Hepatol. 2018 Apr;3(4):252-262. doi: 10.1016/S2468-1253(18)30003-7.

* First epidemiology data on FD using Rome IV criteria. 
82. Van den Houte K, Carbone F, Pannemans J, Corsetti M, Fischler B, Piessevaux $\mathrm{H}$, Tack J. Prevalence and impact of self-reported irritable bowel symptoms in the general population. United European Gastroenterol J. 2019 Mar;7(2):307-315.

83. Pleyer C, Bittner H, Locke GR 3rd, Choung RS, Zinsmeister AR, Schleck CD, Herrick LM, Talley NJ. Overdiagnosis of gastro-esophageal reflux disease and underdiagnosis of functional dyspepsia in a USA community. Neurogastroenterol Motil. 2014;26:1163-71.

84. Corinaldesi R, Stanghellini V, Raiti C, Rea E, Salgemini R, Barbara L. Effect of chronic administration of cisapride on gastric emptying of a solid meal and on dyspeptic symptoms in patients with idiopathic gastroparesis. Gut. 1987 Mar;28(3):300-5.

85. Richards RD, Valenzuela GA, Davenport KG, Fisher KL, McCallum RW. Objective and subjective results of a randomized, double-blind, placebo-controlled trial using cisapride to treat gastroparesis. Dig Dis Sci. 1993 May;38(5):811-6.

86. U.S. Department of Health and Human Services FDA Center for Drug Evaluation and Research; U.S. Department of Health and Human Services FDA Center for Biologics Evaluation and Research; U.S. Department of Health and Human Services FDA Center for Devices and Radiological Health. Guidance for industry: patient-reported outcome measures: use in medical product development to support labeling claims: draft guidance. Health Qual Life Outcomes 2006; 4: 79.

87. Janssen $P$, Harris MS, Jones M, Masaoka T, Farré R, Törnblom H, Van Oudenhove L, Simrén M, Tack J. The relation between symptom improvement and gastric emptying in the treatment of diabetic and idiopathic gastroparesis. Am J Gastroenterol. 2013 Sep;108(9):1382-91.

88. https://www.fda.gov/regulatory-information/search-fda-guidancedocuments/gastroparesis-clinical-evaluation-drugs-treatment

* FDA guidance on design and endpoint for studies with prokinetics in gastroparesis.

89. Parkman HP, Yates K, Hasler WL, et al. Clinical features of idiopathic gastroparesis vary with sex, body mass, symptom onset, delay in gastric emptying, and gastroparesis severity. Gastroenterology. 2011;140:101-115

90. Revicki DA, Speck RM, Lavoie S, Puelles J, Kuo B, Camilleri M, Almansa C, Parkman HP. The American neurogastroenterology and motility society gastroparesis cardinal symptom index-daily diary (ANMS GCSI-DD): 
Psychometric evaluation in patients with idiopathic or diabetic gastroparesis. Neurogastroenterol Motil. 2019 Apr;31(4):e13553.

91. Carbone F, Vandenberghe A, Holvoet L, Vanuytsel T, Van Oudenhove L, Jones M, Tack J. Validation of the Leuven Postprandial Distress Scale, a questionnaire for symptom assessment in the functional dyspepsia/postprandial distress syndrome. Aliment Pharmacol Ther. 2016 Nov;44(9):989-1001.

* Validation of a patient-reported outcome for FD/PDS.

92. Taylor F, Higgins S, Carson RT, Eremenco S, Foley C, Lacy BE, Parkman HP, Reasner DS, Shields AL, Tack J, Talley NJ; Patient-Reported Outcome Consortium's Functional Dyspepsia Working Group. Development of a SymptomFocused Patient-Reported Outcome Measure for Functional Dyspepsia: The Functional Dyspepsia Symptom Diary (FDSD). Am J Gastroenterol. 2018 Jan;113(1):39-48.

* Initial steps in the development of a patient-reported outcome for FD.

93. Tack J, Talley NJ, Camilleri M, Holtmann G, Hu P, Malagelada JR, Stanghellini V. Functional gastroduodenal disorders. Gastroenterology. 2006 Apr;130(5):146679.

94. Carbone F, Holvoet L, Tack J. Rome III functional dyspepsia subdivision in PDS and EPS: recognizing postprandial symptoms reduces overlap. Neurogastroenterol Motil. 2015 


\section{Tables}

Table 1. Rome IV criteria for functional dyspepsia, postprandial distress syndrome (PDS) and epigastric pain syndrome (EPS).

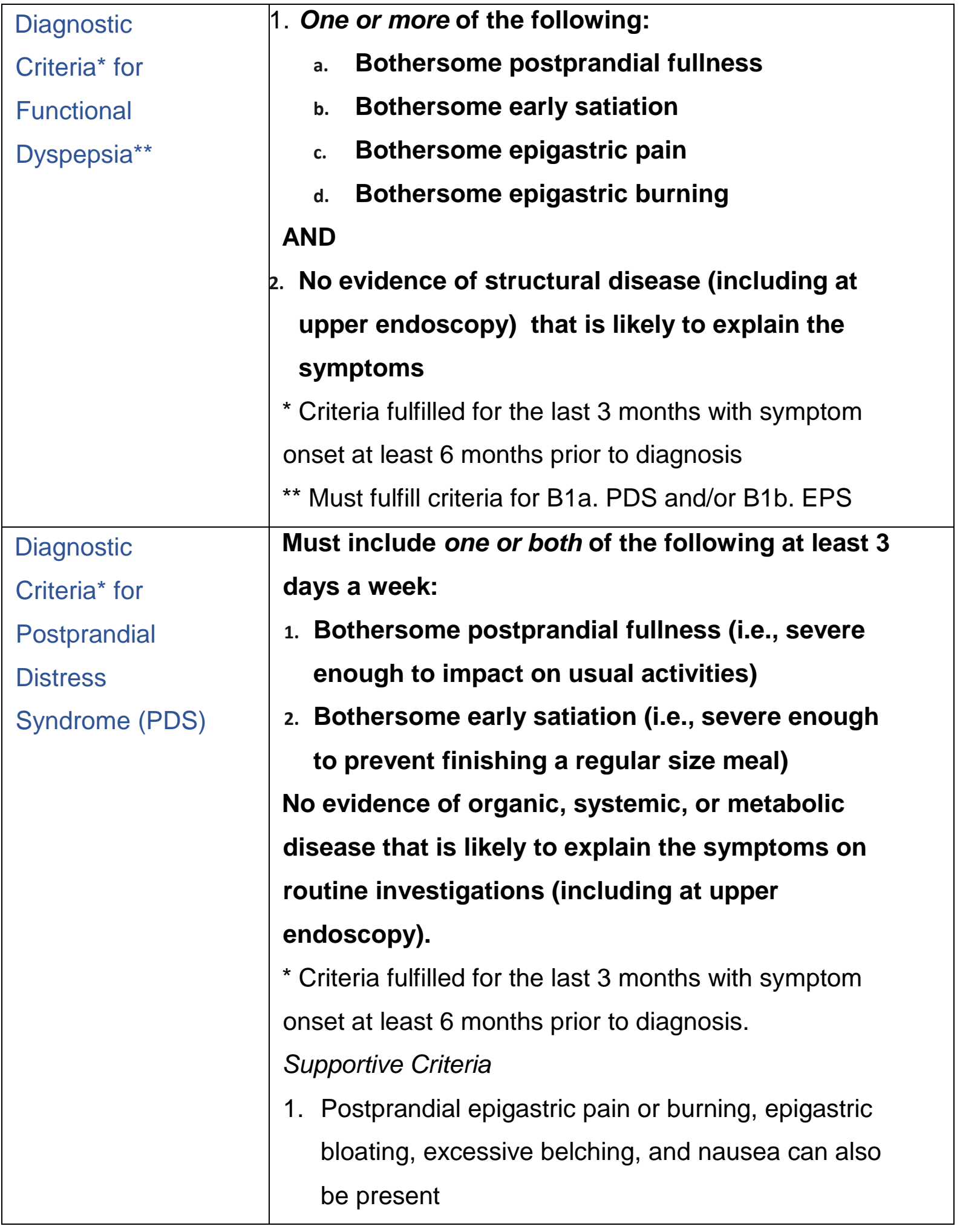




\begin{tabular}{|c|c|}
\hline & $\begin{array}{l}\text { 2. Vomiting warrants consideration of another disorder } \\
\text { 3. Heartburn is not a dyspeptic symptom but may often } \\
\text { co- exist } \\
\text { 4. Symptoms that are relieved by evacuation of feces } \\
\text { or gas should generally not be considered as part of } \\
\text { dyspepsia } \\
\text { 5. Other individual digestive symptoms or groups of } \\
\text { symptoms (e.g., from GERD and IBS) may co- exist } \\
\text { with PDS }\end{array}$ \\
\hline $\begin{array}{l}\text { Diagnostic } \\
\text { Criteria* for }^{*} \\
\text { Epigastric Pain } \\
\text { Syndrome (EPS) }\end{array}$ & $\begin{array}{l}\text { Must include one or both of the following symptoms } \\
\text { at least } 1 \text { day a week: } \\
\text { 1. Bothersome epigastric pain (i.e., severe enough } \\
\text { to impact on usual activities) } \\
\text { 2. Bothersome epigastric burning (i.e., severe } \\
\text { enough to impact on usual activities) } \\
\text { No evidence of organic, systemic, or metabolic } \\
\text { disease that is likely to explain the symptoms on } \\
\text { routine investigations (including at upper } \\
\text { endoscopy). } \\
\text { * Criteria fulfilled for the last } 3 \text { months, with symptom } \\
\text { onset at least } 6 \text { months prior to diagnosis. } \\
\text { Supportive Criteria } \\
\text { 1. Pain may be induced by ingestion of a meal, } \\
\text { relieved by ingestion of a meal, or may occur while } \\
\text { fasting } \\
\text { 2. Postprandial epigastric bloating, belching, and } \\
\text { nausea can also be present } \\
\text { 3. Persistent vomiting likely suggests another disorder } \\
\text { 4. Heartburn is not a dyspeptic symptom but may often } \\
\text { co- exist } \\
\text { 5. The pain does not fulfill biliary pain criteria }\end{array}$ \\
\hline
\end{tabular}


6. Symptoms that are relieved by evacuation of feces or gas generally should not be considered as part of dyspepsia

7. Other digestive symptoms (such as GERD and IBS) may co- exist with EPS 
Table 2. Drugs under development or being studied for functional dyspepsia treatment, and their approval or development status.

\begin{tabular}{|c|c|}
\hline Drug class and agent & Status of development / availability \\
\hline \multicolumn{2}{|l|}{ Acid suppressive drugs } \\
\hline Histamine-2 receptor antagonists & $\begin{array}{l}\text { Approved worldwide for acid-related } \\
\text { disorders (peptic ulcer, reflux esophagitis, } \\
\text { reflux disease). Not approved for functional } \\
\text { dyspepsia. No ongoing development for FD. }\end{array}$ \\
\hline Proton pump inhibitors & $\begin{array}{l}\text { Approved worldwide for acid-related } \\
\text { disorders (peptic ulcer, reflux esophagitis, } \\
\text { reflux disease), H. pylori eradication and } \\
\text { Zollinger-Ellison syndrome. Not approved } \\
\text { for functional dyspepsia. No ongoing } \\
\text { development for FD. }\end{array}$ \\
\hline Potassium-competitive acid pump blockers & $\begin{array}{l}\text { Approved in different parts of the world for } \\
\text { acid-related disorders (peptic ulcer, reflux } \\
\text { esophagitis, reflux disease), H. pylori } \\
\text { eradication and Zollinger-Ellison syndrome. } \\
\text { Not approved for functional dyspepsia. }\end{array}$ \\
\hline \multicolumn{2}{|l|}{ Dopamine-2 receptor antagonists } \\
\hline Domperidone & $\begin{array}{l}\text { Not approved in U.S.A., but can be used } \\
\text { through an FDA IND. }\end{array}$ \\
\hline & $\begin{array}{l}\text { Available in most other parts of the world, } \\
\text { but restricted usage recommendations due } \\
\text { to concerns over QT prolongation risk. }\end{array}$ \\
\hline Itopride & $\begin{array}{l}\text { Development for FD stopped after negative } \\
\text { phase } 3 \text { trials in Europe and North America. }\end{array}$ \\
\hline & $\begin{array}{l}\text { Available in several Asian and some } \\
\text { Eastern European countries. }\end{array}$ \\
\hline TAK-906 & $\begin{array}{l}\text { Phase } 2 \text { for gastroparesis ongoing in } \\
\text { Europe and North America. No ongoing } \\
\text { development for FD. }\end{array}$ \\
\hline \multicolumn{2}{|l|}{ Serotonin-4 receptor agonists } \\
\hline Cisapride & Withdrawn in almost all of the world. \\
\hline Mosapride & $\begin{array}{l}\text { Available in several Asian countries. } \\
\text { Development for FD stopped after a } \\
\text { negative phase } 2 \text { trial in Europe. }\end{array}$ \\
\hline Tegaserod & $\begin{array}{l}\text { Was approved for IBS-C and chronic } \\
\text { constipation in North America, Switzerland } \\
\text { and several South-American countries. } \\
\text { Withdrawn for suspected cardiovascular } \\
\text { issues. Reintroduced in the U.S.A. for } \\
\text { treatment of women with IBS-C in } 2019 \text {. }\end{array}$ \\
\hline
\end{tabular}




\begin{tabular}{|c|c|}
\hline & $\begin{array}{l}\text { Development for FD stopped after phase } 3 \\
\text { trials in North America, due to the above } \\
\text { mentioned cardiovascular issues. }\end{array}$ \\
\hline \multirow[t]{2}{*}{ Prucalopride } & $\begin{array}{l}\text { Approved for chronic constipation in most } \\
\text { parts of the world. }\end{array}$ \\
\hline & $\begin{array}{l}\text { A single-center study shows efficacy in } \\
\text { idiopathic gastroparesis. No ongoing } \\
\text { development for FD. }\end{array}$ \\
\hline \multirow[t]{2}{*}{ Velusetrag } & $\begin{array}{l}\text { Phase } 2 \text { study in gastroparesis suggestive } \\
\text { of efficacy in the idiopathic subgroup. }\end{array}$ \\
\hline & $\begin{array}{l}\text { Phase } 3 \text { studies in idiopathic gastroparesis } \\
\text { planned for } 2019 \text {. }\end{array}$ \\
\hline \multicolumn{2}{|l|}{ Other agents } \\
\hline \multirow[t]{3}{*}{ Acotiamide } & Approved in Japan and India for FD. \\
\hline & $\begin{array}{l}\text { Phase } 3 \text { long-term safety study in FD } \\
\text { finalized in Europe; pivotal phase } 3 \text { efficacy } \\
\text { studies not started. }\end{array}$ \\
\hline & $\begin{array}{l}\text { Phase } 2 \text { study in FD conducted in North } \\
\text { America, but no further development } \\
\text { afterwards. }\end{array}$ \\
\hline Azapirones & $\begin{array}{l}\text { Buspirone and tandospirone approved for } \\
\text { anxiety disorders. No approval for FD. No } \\
\text { ongoing development for FD. }\end{array}$ \\
\hline \multicolumn{2}{|l|}{ Anti-nauseants and anti-emetics } \\
\hline Serotonin-3 receptor antagonists. & $\begin{array}{l}\text { Approved for chemotherapy-induced } \\
\text { nausea and vomiting. No ongoing } \\
\text { development for FD. }\end{array}$ \\
\hline Neurokinin-1 receptor antagonists. & $\begin{array}{l}\text { Approved for chemotherapy-induced } \\
\text { nausea and vomiting. No ongoing } \\
\text { development for FD. Aprepitant showed } \\
\text { potential efficacy in gastroparesis. }\end{array}$ \\
\hline \multicolumn{2}{|l|}{ Centrally acting neuromodulators } \\
\hline Tricyclic antidepressants, mirtazapine & $\begin{array}{l}\text { Approved worldwide for depression. No } \\
\text { approval for FD. No ongoing development } \\
\text { for FD. }\end{array}$ \\
\hline \multicolumn{2}{|l|}{ Peripherally acting neuromodulators } \\
\hline Guanylate cyclase agonist IW-9179 & $\begin{array}{l}\text { Development stopped after negative phase } \\
\text { 2a studies in FD and in gastroparesis. }\end{array}$ \\
\hline MAG lipase inhibitor ABX-1431 & $\begin{array}{l}\text { Development stopped after negative phase } \\
\text { 2a study in FD. }\end{array}$ \\
\hline Cannabinoid type 2 agonist olorinab & $\begin{array}{l}\text { Under development for chronic abdominal } \\
\text { pain in IBD and in functional disorders. }\end{array}$ \\
\hline \multicolumn{2}{|l|}{ Pre-, pro- and antibiotics } \\
\hline
\end{tabular}




\begin{tabular}{|l|l|}
\hline Probiotics & $\begin{array}{l}\text { None approved. Very little ongoing studies } \\
\text { for FD. }\end{array}$ \\
\hline Rifaximin & $\begin{array}{l}\text { Approved in North America and several } \\
\text { other parts of the world for the treatment of } \\
\text { non-constipated IBS. No approval for FD. }\end{array}$ \\
\hline Phytotherapeutic agents & $\begin{array}{l}\text { Available in Europe and North America for } \\
\text { over-the-counter use. No approval for FD. }\end{array}$ \\
\hline Iberogast & $\begin{array}{l}\text { Available in Europe and North America for } \\
\text { over-the-counter use. No approval for FD. }\end{array}$ \\
\hline Peppermint oil / carraway oil & $\begin{array}{l}\text { Approved in Japan for treatment of chronic } \\
\text { gastric symptoms. Ongoing efficacy studies } \\
\text { in FD in Europe. }\end{array}$ \\
\hline Rikkunshito & \multicolumn{2}{|l|}{} \\
\hline Mucosa targeting agents & $\begin{array}{l}\text { Approved in a number of Asian countries for } \\
\text { the treatment of gastritis. No approval for } \\
\text { FD. }\end{array}$ \\
\hline Rebamipide & $\begin{array}{l}\text { Approved for respectively allergy and acid } \\
\text { peptic disease treatment. No approval for } \\
\text { FD. }\end{array}$ \\
\hline $\begin{array}{l}\text { Combination of histamine-1 and histamine- } \\
\text { antagonists }\end{array}$ & $\begin{array}{l}\text { Approved for asthma and chronic } \\
\text { obstructive pulmonary disease. No approval } \\
\text { for FD. }\end{array}$ \\
\hline $\begin{array}{l}\text { Leucotriene-1 receptor antagonist } \\
\text { montelukast }\end{array}$ & \multicolumn{2}{|l}{} \\
\hline
\end{tabular}


Table 3. Overview of the findings in the main controlled trials and meat-analyses in FD.

\begin{tabular}{|c|c|c|c|c|c|c|c|}
\hline \multirow{2}{*}{$\begin{array}{l}\text { Reference } \\
\text { Moayyedi P. } \\
{ }_{12}\end{array}$} & Primary endpoint & Population & \multicolumn{2}{|c|}{ Treatment } & \multirow{2}{*}{$\begin{array}{l}\text { Duration } \\
\text { placebo }\end{array}$} & $\begin{array}{l}\text { Findings } \\
\text { Efficacy }\end{array}$ & fety \\
\hline & $\begin{array}{l}\text { Meta-analysis } \\
\text { of efficacy of } \\
\text { proton pump } \\
\text { inhibitors in } \\
\text { FD }\end{array}$ & $\begin{array}{l}\text { Non-ulcer } \\
\text { FD } \\
\text { patients } \\
(\mathrm{n}=3293)\end{array}$ & PPI therapy & $\begin{array}{l}2-8 \\
\text { weeks }\end{array}$ & & $\begin{array}{l}\text { no or minimal symptoms in } 33 \% \text { for PPI vs. } 23 \% \text { for placebo } \\
(p=0.003) \\
\text { - relative risk of persistent FD with PPI vs. placebo: } 0.86 \\
\text { - number needed to treat: } 9\end{array}$ & - not reported \\
\hline $\begin{array}{l}\text { Pittayanon } \\
\text { R. }{ }^{17}\end{array}$ & Efficacy & $\begin{array}{l}\text { FD patients } \\
(n=10044)\end{array}$ & $\begin{array}{l}\text { cisapride } \\
\text { acotiamide } \\
\text { itopride } \\
\text { tegaserod } \\
\text { mosapride } \\
\text { ABT-229 }\end{array}$ & I & $\begin{array}{l}\text { Placebo } \\
\quad \text { or } \\
\text { Domperidone } \\
\text { 10mg t.i.d. }\end{array}$ & $\begin{array}{l}\text { - symptom improvement in } 40 \% \text { for prokinetic agents vs. } 26.1 \% \text { for } \\
\text { placebo } \\
\text { - no difference between domperidone and other prokinetic agents } \\
\text { - significant symptom improvement with cisapride, acotiamide, } \\
\text { tegaserod } \\
\text { - Tendency for improvement with itopride }\end{array}$ & $\begin{array}{l}\text { - AEs in } 29.3 \% \text { of the patients for } \\
\text { prokinetic agents (cisapride, } \\
\text { acotiamide, itopride and } \\
\text { mosapride) vs. } 30.8 \% \text { for placebo } \\
\text { diarrhoea, abdominal discomfort, } \\
\text { nausea }\end{array}$ \\
\hline $\begin{array}{l}\text { Carbone F. } \\
18\end{array}$ & Efficacy & $\begin{array}{l}\text { FD-PDS } \\
\text { patients } \\
(\mathrm{n}=100)\end{array}$ & $\begin{array}{l}\text { itopride } \\
100 \mathrm{mg} \text { t.i.d. }\end{array}$ & 8 weeks & placebo & $\begin{array}{l}\text { - Improvedsymptom scores after itopride compared to baseline } \\
\text { - } p>0.001) \text {, driven by EPS-PDS overlap group } \\
\text { - No significant change from baseline for placebo }\end{array}$ & - not reported (abstract only) \\
\hline Vakil N. ${ }^{24}$ & $\begin{array}{l}\text { Efficacy in two } \\
\text { trials }\end{array}$ & $\begin{array}{l}\text { FD-PDS } \\
\text { patients } \\
(\mathrm{n}=1134)\end{array}$ & $\begin{array}{l}\text { tegaserod } \\
6 \mathrm{mg} \text { t.i.d. }\end{array}$ & 6 weeks & placebo & $\begin{array}{l}\text { - Improvement of symptoms after tegaserod: } \\
\circ \text { trial } 1: 32.2 \% \text { vs. } 26.6 \%(p<0.01) \\
\circ \text { trial } 2: 31.9 \% \text { vs. } 29.4 \%(p: 0.07) \\
\text { - } \downarrow \text { severity of FD symptoms: } \\
\circ \text { trial } 1: \text { all symptoms }(p>0.03) \\
\quad \text { trial } 2: \text { postprandial fullness }(p=0.04) \\
\text { - Better effect size in those with more than mild dyspepsia severity at } \\
\text { baseline }\end{array}$ & $\begin{array}{l}\text { - most commonly reported: } \\
\text { diarrhoea, headache, nausea } \\
\text { - diarrhoea more common after } \\
\text { tegaserod vs. placebo }\end{array}$ \\
\hline${ }_{29}^{\text {Matsueda K. }}$ & Efficacy & $\begin{array}{l}\text { FD patients } \\
(\mathrm{n}=892)\end{array}$ & $\begin{array}{l}\text { acotiamide } \\
\text { 100mg t.i.d. }\end{array}$ & 4 weeks & placebo & $\begin{array}{l}\text { - Increased response rate for acotiamide }(52.2 \%) \text { vs. placebo } \\
(34.8 \%)(p<0.01) \\
\text { - Increased elimination rate of postprandial fullness, upper abdominal } \\
\text { bloating and early satiation ( } 15.3 \%) \text { vs. placebo }(9 \%)(p<0.01) \\
\text { - Larger improvement in quality of life after acotiamide }(p<0.01)\end{array}$ & $\begin{array}{l}\text { - } \mathrm{AE} \text { in } 56 \% \text { for acotiamide and } \\
60.4 \% \text { for placebo } \\
\text { - most common: elevated serum } \\
\text { triglycerides, serum prolactin, } \\
\text { serum } \mathrm{-} \text {-glutamyl transferase } \\
\text { (yGT); nasopharyngitis. }\end{array}$ \\
\hline Matsueda K. $_{30}$ & $\begin{array}{l}\text { Efficacy and } \\
\text { safety }\end{array}$ & $\begin{array}{l}\text { FD patients } \\
(\mathrm{n}=405)\end{array}$ & $\begin{array}{l}\text { acotiamide } \\
\text { 100mg t.i.d. }\end{array}$ & 48 weeks & I & $\begin{array}{l}\text { - Increasing efficacy from } 26.1 \% \text { at week } 1 \text { to } 60.6 \% \text { at week } 8 \\
\text { - Increasing rate of symptom elimination up to week } 8 \\
\text { - } 13.6 \% \text { withdrew due to poor response } \\
\text { - } 38.0 \% \text { discontinued due to remission of symptoms }\end{array}$ & $\begin{array}{l}\text { - AE incidence rate: } 72.5 \% \\
\text { - AR incidence rate: } 11.5 \% \\
\text { - ARs: constipation, diarrhoea, } \\
\text { ALT, prolactin levels, yGT }\end{array}$ \\
\hline Tack J. ${ }^{31}$ & $\begin{array}{l}\text { Long-term } \\
\text { safety and } \\
\text { efficacy }\end{array}$ & $\begin{array}{l}\text { FD-PDS } \\
\text { patients } \\
(n=168)\end{array}$ & $\begin{array}{l}\text { acotiamide } \\
\text { 100mg t.i.d. }\end{array}$ & 52 weeks & / & $\begin{array}{l}\text { - Improvement of early satiation, postprandial fullness and upper } \\
\text { abdominal bloating after } 2,1 \text { and } 8 \text { weeks respectively } \\
\text { - } 70.2 \% \text { moderate or strong improvement } \\
\text { - improved quality of life }\end{array}$ & $\begin{array}{l}\text { - } 44.4 \% \text { treatment-emergent AEs: } \\
\text { hoad common: influenza, } \\
\text { - } 8.7 \% \text { related to treatment: } \\
\text { nausea, abdominal distension, } \\
\text { constipation }\end{array}$ \\
\hline Tack J. ${ }^{33}$ & $\begin{array}{l}\text { Efficacy and } \\
\text { mechanism }\end{array}$ & $\begin{array}{l}\text { FD patients } \\
(\mathrm{n}=17)\end{array}$ & $\begin{array}{l}\text { buspirone } \\
\text { (10mg ti.i.d.) }\end{array}$ & 4 weeks & placebo & $\begin{array}{l}\text { - Improvement of overall FD symptoms after buspirone vs. placebo } \\
\text { - Improves) } \\
\text { bloating after buspirone }(p<0.005) \\
\text { - no effect of placebo }\end{array}$ & - not reported \\
\hline
\end{tabular}




\begin{tabular}{|c|c|c|c|c|c|c|c|}
\hline Miwa H. ${ }^{34}$ & Efficacy & $\begin{array}{l}\text { FD patients } \\
(n=144)\end{array}$ & $\begin{array}{l}\text { Tandospirone } \\
10 \text { mg t.i.d. }\end{array}$ & 4 weeks & Placebo & $\begin{array}{l}\text { - Signifianclty larger improvement in total symptom score with } \\
\text { tandospirone over placebo } \\
\text { - Significantly greater improvements with tandospirone group for } \\
\text { upper abdominal pain }(P=0.02) \text { and discomfort }(P=0.002) \text { at week } \\
\text { 4. } \\
\text { - Significanlty greater proportion of responders with tandospirone at } \\
\text { week } 4(31.5 \text { vs. } 12.7 \%, p=0.0016) \text {. } \\
\text { - Significant improvements in anxiety in both arms }\end{array}$ & $\begin{array}{l}\text { - No SAEs } \\
\text { - AEs similar in both arms }\end{array}$ \\
\hline Tack J. ${ }^{35}$ & $\begin{array}{l}\text { Efficay and } \\
\text { mechanism }\end{array}$ & $\begin{array}{l}\text { FD patients } \\
\text { with } \\
\text { impaired } \\
\text { accommod } \\
\text { ation or } \\
\text { visceral } \\
\text { hypersensit } \\
\text { ivity ( } \mathrm{n}=53 \text { ) }\end{array}$ & $\begin{array}{l}\text { R-137696 } 2 \mathrm{mg} \\
\text { t.i.d }\end{array}$ & 4 weeks & Placebo & $\begin{array}{l}\text { - No difference in overall symptom improvement between both } \\
\text { treatments } \\
\text { - Placebo was superior for the subscales of early satiety, bloating, } \\
\text { fullness and discomfort (all } \mathrm{P}<0.05 \text { ) } \\
\text { - No difference in effects on accommodation and gastric sensitivity, } \\
\text { measured with the barostat }\end{array}$ & - No SAEs \\
\hline Talley NJ. ${ }^{50}$ & $\begin{array}{l}\text { Adequate relief } \\
\text { of FD } \\
\text { symptoms }\end{array}$ & $\begin{array}{l}\text { FD patients } \\
(\mathrm{n}=292)\end{array}$ & $\begin{array}{l}\text { amitriptyline } \\
50 \mathrm{mg} \text { q.d. }\end{array}$ & 10 weeks & $\begin{array}{l}\text { placebo } \\
\text { OR } \\
\text { escitalopram } \\
10 \mathrm{mg} \text { once } \\
\text { daily }\end{array}$ & $\begin{array}{l}\text { - Adequate symptom relief: } 40 \% \text { for placebo, } 53 \% \text { for amitriptyline } \\
\text { ( } p=0.07 \text { vs placebo), } 38 \% \text { for escitalopram ( } p=0.65 \text { vs. placebo) } \\
\text { - Larger effect in ulcer-like FD: adequate relief in } 39 \% \text { after placebo, } \\
67 \% \text { after amitriptyline, } 27 \% \text { after escitalopram } \\
\text { - No difference in treatment response for dysmotility-like FD patients } \\
\text { - Similar improvement in quality of life in both antidepressant arms, } \\
\text { higher than placebo ( } p=0.02 \text { ) } \\
\text { - } 73 \% \text { relapsed: no difference between all treatment arms }\end{array}$ & $\begin{array}{l}\text { - abdominal pain, suicidal } \\
\text { thoughts, dizziness, drowsiness }\end{array}$ \\
\hline $\begin{array}{l}\text { Van } \\
\text { Kerkhoven } \\
\text { LA. } 52\end{array}$ & Efficacy & $\begin{array}{l}\text { FD patients } \\
(n=160)\end{array}$ & $\begin{array}{l}\text { venlafaxine } \\
75-150 \mathrm{mg} \text { q.d. }\end{array}$ & 8 weeks & placebo & $\begin{array}{l}\text { - Symptom-free after } 8 \text { weeks: } 37 \% \text { for venlafaxine vs. } 39 \% \text { for } \\
\text { placebo (N.S.); no improvement in individual symptoms } \\
\text { - Larger dropout rates in the venlafaxine group } \\
\text { - Compared to baseline: } \\
\quad \text { Decreased mean number of symptoms in both groups } \\
\circ \quad \text { Lower depression and anxiety scores after venlafaxine } \\
\circ \quad \text { Improved quality of life after venlafaxine } \\
\text { - No significant differences between both treatment groups }\end{array}$ & $\begin{array}{l}\text { nausea, palpitations, sweating, } \\
\text { sleeping disorder, dizziness, } \\
\text { visual impairment }\end{array}$ \\
\hline Tack J. ${ }^{53}$ & Efficacy & $\begin{array}{l}\text { FD patients } \\
\text { with weight } \\
\text { loss } \\
(n=34)\end{array}$ & $\begin{array}{l}\text { mirtazapine } \\
15 \mathrm{mg} \mathrm{q.d.}\end{array}$ & 8 weeks & placebo & $\begin{array}{l}\text { - Decreased symptom severity after mirtazapine for } 4 \text { weeks }(p<0.01) \\
\text { and } 8 \text { weeks }(p=0.02) \text { vs. baseline; no difference in symptom } \\
\text { severity after placebo } \\
\text { - No significant difference in symptom severity between placebo and } \\
\text { mirtazapine after } 4 \text { weeks }(p=0.06) \text { and } 8 \text { weeks }(p=0.55) \\
\text { - Improved early satiation after mirtazapine for } 4 \text { weeks }(p<0.01) \text { and } \\
8 \text { weeks }(p<0.01) \text { vs. baseline; no difference after placebo } \\
\text { - Improved early satiation with mirtazapine after } 4 \text { weeks }(p=0.02) \\
\text { and } 8 \text { weeks }(p<0.01) \text { vs. placebo } \\
\text { - Larger weight recovery after mirtazapine }(p<0.01) \\
\text { - improved quality of life after mirtazapine vs. placebo }(p=0.03) \\
\text { - Lower anxiety scores after } 8 \text { weeks of mirtazapine }(p<0.05)\end{array}$ & $\begin{array}{l}\text { - fatigue, sleepiness } \\
\text { - no SAEs }\end{array}$ \\
\hline Tan V. ${ }^{64}$ & Efficacy & $\begin{array}{l}\text { FD patients } \\
\text { who are } \mathrm{H} \text {. } \\
\text { pylori } \\
\text { negative } \\
(\mathrm{n}=86)\end{array}$ & $\begin{array}{l}\text { Rifaximin } 400 \\
\text { mg t.i.d. }\end{array}$ & $\begin{array}{l}2 \text { weeks } \\
\text { treatment } \\
\text {; followed } \\
\text { up for } 8 \\
\text { weeks }\end{array}$ & placebo & $\begin{array}{l}\text { - Adequate relief reported by } 78 \% \text { after rifaximin vs. } 52 \% \text { after } \\
\text { placebo }(p=0.02) \\
\text { - Rifaximin was also superior to placebo in providing adequate relief } \\
\text { of belching and post-prandial fullness/bloating after } 4 \text { weeks } \\
\text { - female subjects had more significant response to rifaximin } \\
\text { treatment }\end{array}$ & - AEs similar in both groups \\
\hline
\end{tabular}




\begin{tabular}{|c|c|c|c|c|c|c|c|}
\hline Melzer ${ }^{56}$ & $\begin{array}{l}\text { Meta-analysis } \\
\text { of efficacy of } \\
\text { STW-5 } \\
\text { (iberogast) in } \\
\text { FD }\end{array}$ & $\begin{array}{l}\text { Non-ulcer } \\
\text { FD } \\
\text { patients } \\
(\mathrm{n}=397)\end{array}$ & STW-5 therapy & 4 weeks & placebo & $\begin{array}{l}\text { STW- } 5 \text { more effective than placebo for improving the most } \\
\text { bothersome symptom }(p<0.01) \\
\text { Improvement with STW-5 most pronounced for epigastric pain, } \\
\text { acid regurgitation and retrosternal troubles }\end{array}$ & - AEs similar to placebo \\
\hline May B. ${ }^{66}$ & $\begin{array}{l}\text { Efficacy and } \\
\text { safety }\end{array}$ & $\begin{array}{l}\text { FD patients } \\
(n=96)\end{array}$ & $\begin{array}{l}\text { peppermint oil } \\
\text { (90mg) and } \\
\text { caraway oil } \\
\text { (50mg) ti.i.d. } \\
\text { (POCO) }\end{array}$ & 4 weeks & placebo & $\begin{array}{l}\text { - } 40 \% \text { decrease in intensity of pain after POCO vs. } 22 \% \text { for placebo } \\
(p<0.01) \\
\text { - } 43.5 \% \text { decrease in fullness after POCO vs. } 22.3 \% \text { for placebo } \\
(p<0.01) \\
\text { - } 66 \% \text { much or very much improved after POCO vs. } 20.9 \% \text { for } \\
\text { placebo }(p<0.01)\end{array}$ & $\begin{array}{l}\text { - AEs in } 10.4 \% \text { of POCO group vs. } \\
2.1 \% \text { for placebo } \\
\text { - haemorrhoids, bronchitis, } \\
\text { influenza, mild eructation, severe } \\
\text { nausea and vomiting } \\
\text { - all assessed to be not related or } \\
\text { unlikely to be related to study } \\
\text { medication }\end{array}$ \\
\hline Rich G. ${ }^{67}$ & $\begin{array}{l}\text { Efficacy on } \\
\text { symptoms and } \\
\text { quality of life }\end{array}$ & $\begin{array}{l}\text { FD patients } \\
(\mathrm{n}=114)\end{array}$ & $\begin{array}{l}\text { peppermint oil } \\
\text { (90mg) and } \\
\text { caraway oil } \\
\text { (50mg) } \\
\text { t.i.d.(POCO) }\end{array}$ & 4 weeks & placebo & $\begin{array}{l}\text { - } 62.3 \% \downarrow \text { in pain scores after POCO vs. } 26 \% \text { for placebo ( } p<0.01) \\
\text { - } \text { improvement of } \geq 10 \% \text { in } 86.2 \% \text { of POCO group vs. } 57.1 \% \text { for } \\
\text { placebo }(p<0.01) \\
\text { - } 57.1 \% \downarrow \text { in discomfort after POCO vs. } 20.6 \% \text { for placebo ( } p<0.01) \\
\text { - improvement of } \geq 10 \% \text { in } 88 \% \text { of POCO group vs. } 55.4 \% \text { for placebo } \\
\text { - }(p<0.01) \\
\text { more patients symptom-free after POCO vs. placebo } \\
\text { - } \text { stronger } \downarrow \text { in EPS and PDS symptom scores after POCO vs. } \\
\text { placebo } \\
\text { - } \text { stronger improvementin quality of life after POCO }\end{array}$ & $\begin{array}{l}\text { - AEs in } 19 \% \text { of POCO group vs. } \\
8.9 \% \text { for placebo } \\
\text { possibly related: eructation, } \\
\text { allergic reaction }\end{array}$ \\
\hline Chey W.D. & Efficacy & $\begin{array}{l}\text { FD patients } \\
(n=53)\end{array}$ & $\begin{array}{l}\text { peppermint and } \\
\text { caraway oil } \\
\text { (POCO) }\end{array}$ & 4 weeks & placebo & $\begin{array}{l}\text { - Proportion of patients who were "much" or "very much" improved: } \\
\circ 78 \% \text { PDS vs. } 50 \% \text { placebo }(p=0.09) \\
\circ 72 \% \text { EPS vs. } 40 \% \text { placebo }(p<0.05) \\
\text { - PDS: improved sensation of pressure, heaviness, fullness } \\
\text { - EPS: improved epigastric pain or discomfort }\end{array}$ & - not reported \\
\hline $\begin{array}{l}\text { Suzuki H. } \\
71\end{array}$ & $\begin{array}{l}\text { Efficacy and } \\
\text { safety }\end{array}$ & $\begin{array}{l}\text { FD patients } \\
(n=247)\end{array}$ & $\begin{array}{l}\text { rikkunshito } \\
2.5 \mathrm{~g} \text { t.i.d. }\end{array}$ & 8 weeks & placebo & $\begin{array}{l}\text { - } 33.6 \% \text { responders in rikkunshito group vs. } 23.8 \% \text { in placebo group } \\
\text { ( } p=0.09) \\
\text { - Efficacy of rikkunshito apparent from week } 4 \text { onwards } \\
\text { - } 44 \% \text { with relief of epigastric pain after rikkunshito vs. } 30.3 \% \text { for } \\
\text { placebo ( } p=0.04) \\
\text { - } 50.4 \% \text { with relief of postprandial fullness after rikkunshito vs. } 37.7 \% \\
\text { for placebo }(p=0.06) \text {, driven by PDS patients } \\
\text { - No difference in relief of epigastric burning and early satiation } \\
\text { between both groups }\end{array}$ & $\begin{array}{l}\text { - AEs in } 15.2 \% \text { of rikkunshito } \\
\text { group vs. } 11.5 \% \text { of placebo } \\
\text { group ( } p=0.46) \\
\text { diarrhoea, nausea, headache, } y \text { - } \\
\text { GT elevation, upper abdominal } \\
\text { pain, alanine transaminase } \\
\text { elevation, abdominal bloating, } \\
\text { abdominal discomfort, } \\
\text { nasopharyngitis, tinnitus, skin } \\
\text { dysesthesia, oral dysesthesia, } \\
\text { dizziness, urticarial }\end{array}$ \\
\hline $\begin{array}{l}\text { Tominaga } \\
\text { K. }{ }^{72}\end{array}$ & $\begin{array}{l}\text { Efficacy and } \\
\text { safety }\end{array}$ & $\begin{array}{l}\text { H. Pylori } \\
\text { negative } \\
\text { FD patients } \\
(\mathrm{n}=128)\end{array}$ & $\begin{array}{l}\text { rikkunshito } \\
7.5 \mathrm{~g} \text { t.i.d. }\end{array}$ & 8 weeks & placebo & $\begin{array}{l}\text { - After } 8 \text { weeks ( } p=0.02) \text { : extremely improved reported by } 8.2 \% \text { for } \\
\text { rikkunshito and } 1.8 \% \text { for placebo; improvement reported by } 29.5 \% \\
\text { for rikkunshito and } 21.1 \% \text { for placebo } \\
\text { - Larger decrease in total symptom score after rikkunshito vs. } \\
\text { placebo }(p=0.02) \\
\text { - Larger decrease in postprandial fullness/early satiety ( } p<0.01) \text { and } \\
\text { bloating }(p<0.01) \text { after } 8 \text { weeks of rikkunshito vs. placebo } \\
\text { - Major effect on PDS scores compared to on EPS scores } \\
\text { - Larger decrease in anxiety scores with rikkunshito }\end{array}$ & $\begin{array}{l}\text { - AEs in } 10.8 \% \text { for rikkunshito vs. } \\
11.1 \% \text { for placebo } \\
\text { - ARs in } 4.6 \% \text { for rikkunshito vs. } \\
1.6 \% \text { for placebo } \\
\text { - no significant difference between } \\
\text { both groups }\end{array}$ \\
\hline $\begin{array}{l}\text { Togawa K. } \\
73\end{array}$ & $\begin{array}{l}\text { Difference in } \\
\text { clinical }\end{array}$ & $\begin{array}{l}\text { FD patients } \\
(\mathrm{n}=125)\end{array}$ & $\begin{array}{l}\text { rikkunshito } \\
2.5 \mathrm{~g} \text { t.i.d. }\end{array}$ & 8 weeks & placebo & - 42 patients were responders vs. 83 were non-responders & - not reported \\
\hline
\end{tabular}


characteristic of

esponders vs.

non-responders
- proportion of responders was higher in patients who abstained from

alcohol vs. social/heavy drinkers

postprandial fullness: $p=0.0$

n: $p<0.01$

proportion of responders was higher in patients with low des-acy

ghrelin at baseline vs. high des-acyl ghrelin in H. Pylori negative 


\section{Figure legends}

Figure 1. Schematic representation of the overlap between the functional dyspepsia subgroups (epigastric pain syndrome, EPS and postprandial distress syndrome, PDS) with idiopathic gastroparesis and with nausea and vomiting disorders as defined by the Rome IV consensus.

Figure 2. Putative pathophysiological mechanisms and emerging therapeutic targets in functional dyspepsia. 